\title{
Qualitative Analysis: Comparison of Growth and Development in Children with HIV/AIDS Living at Lentera Halfway House and Those Living at Home with Family in Surakarta
}

\author{
Vita Raraningrum(1), Argyo Demartoto²), Supriyadi Hadi Respati3) \\ 1)School of Midwifery Rustida, Banyuwangi, East Java \\ 2)Masters Program in Public Health, Universitas Sebelas Maret \\ 3)Department of Obstetrics and Gynecology, Dr. Moewardi Hospital, Surakarta
}

\begin{abstract}
Background: Children with HIV/AIDS infection need optimal endurance to grow and develop. Optimal endurance is required to cope with threatening diseases. This study aimed to compare growth and development in children with HIV/AIDS living at Lentera halfway house and those living at home with family in Surakarta.

Subjects and Method: This was a qualitative study with case study approach. The main study subjects were children with HIV/AIDS. The informants of this study included manager and caregivers at the Lentera halfway house, and parents. The informants were selected by snowball sampling. The dependent variables under study included bodyweight, CD4, fine and gross motoric development, stigma and discrimination, moral and religious development. The independent variable was place of care, i.e. halfway house or home with family. Except for bodyweight and CD4, the other remaining variables were collected by in-depth interview and observation. Bodyweight was measured by scale. CD4 was measured by chemical laboratory.

Results: There was no difference in child growth living in the two places of care, with respect to bodyweight and $\mathrm{CD} 4$ count. The $\mathrm{CD} 4$ count was moderate indicating a moderate immunosuppressive state. Children with HIV/AIDS suffered stigma and discrimination more at halfway house than at home living with family. There was no difference in gross motoric development in children with HIV/AIDS living at the two places of care. Likewise, there was no difference in moral and religious development in children with HIV/AIDS living at the two places of care.

Conclusion: Stigma and discrimination occur more often in children with HIV/AIDS that live at halfway house than at home with family. Bodyweight, CD4 count, gross motoric development, and moral and religious development are comparable in children with HIV/AIDS that live at halfway house and at home with family.
\end{abstract}

Keywords: children with HIV/AIDS, halfway house, family, growth, development

\section{Correspondence:}

Vita Raraningrum. School of Midwifery Rustida, Banyuwangi, East Java. Email: vitarara.11@gmail.com

\begin{tabular}{l}
\hline BACKGROUND \\
Children with HIV are very susceptible to \\
social problems, especially for those who \\
contract HIV from their parents. The most \\
vulnerable problem is being orphaned \\
because one or both of their parents died of \\
AIDS. A study conducted by Abashula et al., \\
(2014) found the problems faced by \\
children with HIV/AIDS, who have been \\
orphaned. A study conducted in Ethiopia
\end{tabular}

found the fact that many children infected with HIV/AIDS experienced health problems, sexual violence, and even many of them had to be employed under age. Another problem faced by children with HIV/ AIDS is that there are still few of them who have access to health and education services.

Nilesh Thakor et al., (2015) said there are various problems faced by children with 
Journal of Epidemiology and Public Health (2016), 1(3): 175-181

https://doi.org/10.26911/jepublichealth.2016.01.03.04

HIV/AIDS. A study conducted on children with HIV/AIDS in the age range of 5-14 years in India revealed various problems faced by children with HIV/AIDS. 30\% of the study respondent children were expelled from school, $65.5 \%$ of children had to live with their parents who also had HIV/AIDS, while $63 \%$ were cases of parents who prefer to keep their children's HIV/ AIDS status confidential, from those around them like teachers and friends. In addition, some children were also found with poor health conditions such as nutritional deficiencies, and even found some children who did not receive ART therapy.

The purpose of this study is to determine the growth and development of children with HIV/AIDS in Surakarta by taking the case of children with HIV/AIDS who were living at Lentera halfway house and those who were living at home with family. Lentera Halfway House is a halfway house that accommodates orphans who are infected with HIV / AIDS in Surakarta.

\section{SUBJECTS AND METHOD}

This was a qualitative study with case study approach. The sampling technique used was snowball sampling. The main informant was children with HIV/AIDS who lived in Lentera Halfway House and who lived with family. Data collection techniques used in this study were depth interviews, observation and document analysis. Data validity in this study included source triangulation, method triangulation, theory triangulation. Data analysis in this study used pairing pattern analysis model namely data reduction, data presentation and data analysis that form a pattern that can reveal growth and development.

\section{RESULTS}

There was no difference in the growth of children with HIV/AIDS who lived in Lentera Halfway Houses with those who lived with families. The medical record data of children with HIV/AIDS showed that there was no difference in weight between children with HIV/AIDS who lived in Lentera Halfway House and those who lived with family or parents. This related to the children with HIV/AIDS (CD4) immune system and the nutrition provided by caregivers or family and parents. Based on the medical record data of Dr.Moewardi hospital, it was known that: CD4 count on child with HIV/ AIDS F was 352 Cells/mm3 (200-499) and child with HIV/AIDS P was 450 Cells/mm3 (200-499) were both in the category of moderate immunosuppression. Whereas, child with HIV/AIDS M/Y and child with HIV/AIDS M/B CD4 count was 5oo Cells / $\mathrm{mm} 3(\geq 500)$ and included in the category of no immunosuppression.

The development of children with HIV/AIDS at Lentera Halfway House and those who live with families included physical, intellectual, emotional, language, social, personality, moral, and religious awareness developments.

The physical development of children with HIV/AIDS was seen from gross motor and fine motor development. Child with HIV/AIDS M/Y gross motor development had been able to jump, catch balls and play sports but could not ride a child's bicycle. Child with HIV/AIDS F had been able to jump, catch the ball and play sports but could not ride a child's bicycle. Child with HIV/AIDS P had been able to jump, catch balls and play sports but could not ride a child's bicycle, and child with HIV/AIDS M.B had been able to jump, catch balls and play sports but could not ride a child's bicycle. Child with HIV/AIDS M/Y fine motor development had been able to use 
pencil and drawing, and had not been able to cut with scissors and write printed letters. Child with HIV/AIDS F could already use pencils, draw, cut with scissors and write letters. Child with HIV/AIDS P had been able to use pencils, draw, cut with scissors and write letters, and child with HIV/AIDS M.B could use pencils, draw, cut with scissors and write.

The intellectual development of child with HIV/AIDS M.Y had not been able to apply the symbol as a whole, but only a few activities such as playing horses, playing war games. The intellectual development of child with HIV/AIDS F could already use pillows or bolster pillows, and tell stories using puppets. The intellectual development of child with HIV/AIDS $\mathrm{P}$ could already use pillows, bolster pillows, chairs, cloth that could be used. The intellectual development of child with HIV/AIDS M.B, in addition to using a bolster pillow, he/she could also use other objects such as straws, blocks, chairs.

The emotional development of child with HIV/AIDS M/Y, child with HIV/AIDS $F$ and child with HIV/AIDS M.B in their development could show expressions of fear, anger, jealousy, pleasure, love, phobia and curiosity. However, feelings of anxiety had not been seen. Whereas, child with HIV/AIDS $\mathrm{P}$ could show expressions of fear, anger, jealousy, pleasure, affection, phobia and curiosity but feelings of anxiety was seen sometimes.

The language development of child with HIV/AIDS F, P and M.B could already use compound sentences and their clauses. Their level of thinking were more advanced. They asked a lot of questions about time, cause and effect through questions: when, where, why, and how. Whereas, child with HIV/AIDS M/Y had not been able to use compound sentences along with their clauses, and his/her level of thinking was more advanced, the child with HIV/AIDS asked a lot of questions about time, cause and effect through questions: when, where, why, and how. Based on the results of the study, it was found that the language development in one child with HIV/AIDS who lived in Lentera Halfway House was still having difficulties, but for children with HIV/AIDS who lived with their families and parents were more advanced in the development of their language.

The social development of child with HIV/AIDS M/Y and child with HIV/AIDS F were limited to Lentera Halfway House or to school. While the social development of child with HIV/AIDS $\mathrm{P}$ and child with HIV/AIDS M.B could interact socially with all their peers at home, school, relatives, or home environment. The social development of children with HIV/AIDS who lived in Lentera Halfway House had a negative stigma from the community (surrounding environment and school environment) because of their positive HIV status. While children with HIV/AIDS who lived with family were relatively more easily accepted by the surrounding community. Children with HIV/AIDS who lived at Lentera Halfway House could not freely interact with others, especially with fellow children in the neighborhood of Lentera Halfway House.

The play development of children with HIV/AIDS M/Y, F, P and M.B, they could play function, fiction, receptive and construction games including jumping, going up and down stairs, running, playing rope, and playing ball, playing chairs as horses, playing school roles, trading roles, playing battles, and cooking; building a house from pieces of wood or plastic and making weapons from banana leaf midrib.

Due to the limited space of the shelter house, there were obstacles to innovation in making games for children with HIV/AIDS 
Journal of Epidemiology and Public Health (2016), 1(3): 175-181

https://doi.org/10.26911/jepublichealth.2016.01.03.04

who lived in Lentera Shelter House compared to children with HIV/AIDS who lived with families. Children with HIV/AIDS who lived with family were more creative in making various games, not only played at home but also outside the house. Children with HIV/AIDS at Lantera Halfway House were more likely to play inside the house because of discrimination. Personality development of children with HIV/AIDS was good. Children with HIV/AIDS M/Y, F.P and M.B had confidence in doing things like singing and praying, including in front of the researcher. Based on initiatives in attitude and behavior, children with HIV/ AIDS M/Y, F.P and M.B could already have an understanding of something that was bad or good. They sometimes spoke gently to the older people.

In moral development, children with HIV/AIDS already had a basis for morality towards their social groups (parents, siblings and peers). Through the experience of interacting with other people (parents, siblings and peers) children learnt to understand which activities or behaviors were good/allowed/accepted/approved or $\mathrm{bad} /$ not allowed/rejected/not approved. Examples made by children with HIV/AIDS included praying before eating and sleeping so they could go to heaven, washing their hands before eating, brushing their teeth before going to bed, and not littering. All stages of moral development were carried out and applied in their daily lives. There was no difference regardig moral development between children with HIV/AIDS who lived in Lentera Halfway House and those who lived with family or parents.

The religious awareness development of children with HIV/AIDS F, P and M.B had been relatively good which includes greeting, saying Basmalah when going to do something, saying Alhamdulillah when getting pleasure or after doing something, respecting others, giving shodaqoh, and maintaining cleanliness (health) of themselves. However, child with HIV/AIDS M/Y couldnot say hello and read Alhamdulillah when getting pleasure and after doing something due to limited language development.

$\frac{\text { DISCUSSION }}{\text { It can be concluded that the growth of }}$
children with HIV/AIDS living in Lentera Halfway House and those who live with families have no difference. The results of medical record data from children with HIV/AIDS informants showed that there were no differences in the parameters of $\mathrm{TB}$ and BB between children with HIV/AIDS who lived in Lentera Halfway House and those who lived with family or parents. This was related to the immune system and the nutrition of children with HIV/AIDS given by caregivers or families.

Based on Moewardi Hospital medical record data, $\mathrm{CD} 4$ cell count in child with HIV/AIDS F was 352 cells/mm3 (200-499) and $\mathrm{CD} 4$ count of child with HIV/AIDS P were 450 cells $/ \mathrm{mm}_{3}$ (200-499). Both were in the category of Moderate Immunosuppression. While the $\mathrm{CD} 4$ count of child with HIV/AIDS M/Y and child with HIV/ AIDS M.B was 500 cells $/ \mathrm{mm}_{3}(\geq 500)$ included in the category of no immunosuppression. Physical development that could be achieved with all aspects between children with HIV/AIDS who lived at Lentera Halfway House and those who lived with families was that only one child $\mathrm{M} / \mathrm{Y}$ had experienced a difference because $\mathrm{M} / \mathrm{Y}$ was constrained by language and concentration.

Aspects in physical development were very important to be applied in everyday life so that every caregiver or child with HIV/AIDS could play more role in his body function, so that he could enjoy the benefits 
of form, each function of the physical development of children. In this development it was assessed from good nutrition and understanding in playing without having to see the illness. Physical development between children with HIV/AIDS who lived at Lentera Halfway House and those who lived with families were good because it was balanced with the love of caregivers and families who always accompany the children.

Intellectual development of child with HIV/AIDS M.Y could not yet implement the symbol as a whole, only a few activities like playing horses and playing war games. Intellectual development of the child with HIV/AIDS F could be seen from he/she could use pillows or bolster pillow and told stories using dolls. The emotional development of children with HIV/AIDS M/Y, F and M.B could already show expression of fear, anger, jealousy, pleasure, affection, phobia and curiosity in their development, but feelings of anxiety had not been seen. Whereas child with HIV / AIDS P could show expressions of fear, anger, jealousy, pleasure, affection, phobia and curiosity, but feelings of anxiety were sometimes seen.

Regarding language development, children with HIV/AIDS F, P and M.B had been able to use compound sentences along with their subordinates, and their level of thinking was more advanced, they asked a lot of questions about time, cause and effect through questions including when, where, why, and how. Meanwhile, child with HIV/AIDS M/Y had not been able to use compound sentences along with their subordinates, and the child's level of thinking was more advanced. The child asked a lot of questions about time, cause and effect through questions: when, where, why, and how. Based on the results of the study, it was found that the language development in one child with HIV/AIDS who lived at Lentera Halfway House still had difficulties in language, but children who lived with families were more advanced in their language development.

The social development of child with HIV/AIDS M/Y and child with HIV/AIDS F were limited only at Lentera Halfway House or at school. While the social development of child with HIV/AIDS P and child with HIV/AIDS M.B, they could interact socially with all their peers at home, school or home environment and with relatives. The social development of children with HIV/AIDS living at Lentera Halfway House had a negative stigma from the community (the surrounding environment, school environment) because of their positive HIV status. While children with HIV/AIDS who lived with families were relatively more easily accepted by the surrounding community. Children with HIV/AIDS who lived at Lentera Halfway House could not freely interact socially, especially with fellow children in their neighborhood.

The social adjustment maturity of children with HIV/AIDS would be greatly helped by providing them opportunities to learn to expand their social relationships, and to obey the rules (discipline). Besides, the social development of children with HIV/AIDS was influenced by family atmosphere, including rules that were still loose, not too binding on children's freedom, children with HIV/AIDS had the opportunity to actively move, play, and be cheerful, all of which had pedagogical values; and children with HIV/AIDS could know and associate with multi-cultural peers, both ethnic, religious and culture. Children with HIV/AIDS who lived at Lentera Halfway House had limited mobility so there were obstacles to innovation in making games, compared to children with HIV/AIDS who lived with families. Children with HIV/ 
Journal of Epidemiology and Public Health (2016), 1(3): 175-181

https://doi.org/10.26911/jepublichealth.2016.01.03.04

AIDS were more creative by making various games and not only done at home but outside the house. Children with HIV/AIDS at Lentera Halfway House were more likely to play indoors because of discrimination.

Psychologically and pedagogically, playing had values that were very valuable for children with HIV/AIDS, because they got a feeling of pleasure, satisfaction, pride, or catharsis (tension relief). By playing children could develop self-confidence, responsibility, and cooperation (willing to work together). Children could develop fantasy, or creativity (especially fiction and construction games). Children could recognize the rules, or norms that applied in groups and learnt to obey them. Children could understand that both themselves and others had strenghts and weaknesses, and children could develop sportsmanship, tolerant of others.

Children with HIV/AIDS M/Y, F.P and M.B had confidence in doing something like singing, praying including performed it in front of the researchers. Based on the initiative in attitude and behavior, children with HIV/AIDS M/Y, F.P and M.B could already understand something good or bad, understand how to talk to older people well and politely.

The development of children with HIV/AIDS's independence and self-confidence attitude was very much related to the way parents, family members and caregivers were treating them. They had a duty and were obliged to protect children with HIV/AIDS from something harmful like the case experienced by children with HIV/ AIDS when moving from the old residence to the new Halfway House. Each parent, family members and caregivers' treatment tended to have a diverse impact on the child's personality.

There was no difference between the children with HIV/AIDS who lived at
Lentera Halfway Houses and with those who lived with families or parents. When introducing concepts of good-bad, rightwrong, or instilling discipline in children, parents or teachers should provide the reason explanation, because if the planting of discipline was not accompanied by an explanation of the reasons, or doctrinal, it usually would produce a blind discipline, especially if accompanied by harsh treatment. The religious awareness development of children with HIV/AIDS F, P and M.B had been relatively good which includes greeting, saying Basmalah when going to do something, saying Alhamdulillah when getting pleasure or after doing something, respecting others, giving shodaqoh, and maintaining cleanliness (health) of themselves. However, child with HIV/ AIDS M/Y couldnot say hello and read Alhamdulillah when getting pleasure and after doing something due to limited language development.

Childhood age is the age of growth and development that greatly requires optimal endurance to grow and develop. If a child is infected with HIV, the most important thing to take action is to provide therapy. However, giving drugs is not as easy as giving drinks to young children. For this reason, the role of parents is needed. Parents must be diligent and regularly give medicines, especially antiviral drugs. The fulfillment of nutrition is useful for balancing the child's immune system, in addition to being able to help kill the virus. In addition, the fulfillment of nutrition is also to provide immune cell supply, especially lymphocyte proliferation so that the cell levels did not rapidly decrease drastically due to lymphocyte cells killed by the virus. In addition, with a better immune system, HIV patients can survive other threatening diseases. 
Children with HIV/AIDS must also be provided with social and psychological assistance, if the environment already knows their status. Thus, when there is an excommunication against them, the children with HIV/AIDS do not become really feel upset. Parents who have children with HIV/AIDS must be able to give appropriate treatment to their children. Their children's future must be considered, so that they are also given education as befits healthy children. The development of children with HIV/AIDS in Surakarta, especially those who live at Lentera Halfway Houses and those who live with families, face complex problems due to discrimination and stigma from the community in children with HIV/AIDS status.

\section{REFERENCE}

$\overline{\text { Abashula (2014). The situation of orphans }}$ and vulnerable children in selected Woredas and towns in Jimma Zone.

Astuti (2014). Implementasi Kebijakan Kesejahteraan dan Perlindungan Anak. Jurnal Sosio Konsepsia 4(1): 215-235.

Nilesh Thakor (2015). Sociodemographic profile and health status of children living with HIV/AIDS attached to an NGO (ADHAR) of Ahmedabad city.

Narendra, Moersintowarti B (2002). Tumbuh Kembang Anak dan Remaja. Jakarta: Sagung Seto.

Hurlock EB (1980). Psikologi perkembangan suatu pendekatan sepanjang rentang kehidupan. (Edisi kelima). Jakarta: Erlangga.

Komisi Penangulangan AIDS Kota Surakarta (2015). Laporan SRAN, SSR, Kegiatan dan Cakupan bulan Desember 2015 .

Moeloeng L (2008). Metodologi Penelitian Kualitatif (Edisi Revisi). Bandung: PT Remaja Rosdakarya.
Nursalam, Kurniawati, Ninuk D (2007). Asuhan dan Keperawatan pada Pasien Terinfeksi HIV/AIDS. Jakarta: Salemba Medika.

Paul ZA (2015). Social Support Disparities among Children affected by HIV/ AIDS in Ghana. Journal of Psychiatry, 18(1):14-161.

Salimo H (2012). Tumbuh Kembang Anak Pada Penyakit Khusus. Cetakan 2, Surakarta, UNS Press.

Saputri LO (2013). Pelaksanaan Intervensi Pencegahan Penularan HIV Dari Ibu Ke Anak (PPIA) Di RSUP Sanglah Denpasar Tahun 2007-2011. Bali: Universitas Udayana.

Shapiro, Roger L, Lockman, Shahin, Ibou T, Stocking, Lisa (2003). Low adherence to recommended infant feeding strategies among HIV-infected women: Results from the pilot phase of a randomized trial to prevent mother to child transmission in Botswana. AIDS Education and Prevention, 15(3): 22130.

Soetjiningsih (2004). Tumbuh kembang remaja dan permasalahannya. Jakarta: CV Sagung Seto.

Soetjiningsih (2016). Tumbuh Kembang Anak. Jakarta: EGC.

Sugiyono (2013). Metode Penelitian Kuantitatif Kualitatif dan R\&D. Bandung: Alfabeta.

WHO (2012). Millenium Development Goals. World Health Organization Indonesia. 